\title{
Mechanism of enhanced performance on a hybrid direct carbon fuel cell using sawdust biofuels
}

Shuangbin $\mathrm{Li}^{1,2}$, Cairong Jiang ${ }^{3}$, Juan Liu ${ }^{1}$, Haoliang Tao ${ }^{1}$, Xie Meng ${ }^{1}$, Paul Connor ${ }^{2}$, Jianing Hui ${ }^{2}$, Shaorong Wang ${ }^{4}$, , Jianjun $\mathrm{Ma}^{3}$, and John T. S. Irvine ${ }^{2, ~ *}$

1 CAS Key Laboratory of Materials for Energy Conversion, Shanghai Institute of Ceramics, Chinese Academy of Sciences (SICCAS), China

2 School of Chemistry, University of St Andrews, KY16 9ST, United Kingdom

3 Department of Materials Science and Engineering, Sichuan University of Science and

Engineering, China

4 School of Chemical Engineering \& Technology, China University of mining and Technology,

China

Abstract: Biomass is expected to play a significant role in power generation in the near future. With the uprising of carbon fuel cells, hybrid direct carbon fuel cells (HDCFCs) show its intrinsic and incomparable advantages in the generation of clean energy with higher efficiency. In this study, two types of biomass treated by physical sieve and pyrolysis from raw sawdust are investigated on an anode-supported HDCFC. The structure and thermal analysis indicate that raw sawdust has well-formed cellulose I phase with very low ash. Electrochemical performance behaviors for sieved and pyrolyzed sawdust combined with various weight ratios of carbonate are compared in $\mathrm{N}_{2}$ and $\mathrm{CO}_{2}$ purge gas. The results show that the power output of sieved sawdust with $789 \mathrm{mWcm}^{-2}$ is superior to that of pyrolyzed sawdust in $\mathrm{CO}_{2}$ flowing, as well as in $\mathrm{N}_{2}$ flowing. The anode reaction mechanism for the discrepancy of two fuels is explained and the emphasis is also placed on the modified oxygen-reduction cycle mechanism of catalytic effects of $\mathrm{Li}_{2} \mathrm{CO}_{3}$ and $\mathrm{K}_{2} \mathrm{CO}_{3}$ salts in promoting cell performance.

Keywords: hybrid direct carbon fuel cell; sieved and pyrolyzed sawdust; electrochemical performance; reaction mechanism

\footnotetext{
* Corresponding author.

E-mail address: srwang@cumt.edu.cn (S. Wang), itsi@st-andrews.ac.uk (JTS. Irvine)
} 


\section{Introduction}

Along with the incredible development of the urbanization and industrialization, especially in China, the demand for fossil fuels including petroleum, natural gas and coal is increasing dramatically. The inevitable resource depletion is one of the driving forces for pursuing alternative energy sources. Biomass including food and non-food sources such as corn, wood chips, leaves and other organic waste is supposed to be an alternative renewable energy resource due to its low emission of $\mathrm{NO}_{\mathrm{x}}$ and $\mathrm{SO}_{\mathrm{x}}$ pollutants and readily availability $[1,2]$. Sawdust is a biomass, containing hemicellulose, cellulose, lignin and minor quantities of minerals. It is generated from wood manufacturing process in large amounts every year as well as available from domestic and industrial refuse as well as agricultural residues. However, the utilization of sawdust is limited due to its low energy density and loose structure characteristics [3].

One of the most efficient ways to utilize sawdust are direct carbon fuel cells (DCFC), in which solid carbon energy is converted into electricity at $80 \%$ efficiency[4], higher efficiencies than most other conversion technologies. The molten carbonate and solid oxide electrolyte based DCFC prototypes have been extensively studied[5, 6]. A recent design is the hybrid direct carbon fuel cell (HDCFC), which is a composite of a solid oxide fuel cell and molten carbonate fuel cell which gives higher power density by extending active reaction sites and limiting the cathode corrosion[ $[7,8]$.

Several investigations into the effect of carbon types, anode microstructure, scaling up of geometric areas and electrochemical mechanisms on HDCFCs[9]. In 
initial development of the HDCFC concept proposed, Nabae[10] compared the specific surface areas of two carbon black materials (XC-72R and Super-S) on the cell performance. The best outputs from the Super-S carbon black fuels were $13.0 \mathrm{mWcm}^{-}$ ${ }^{2}$ at $900{ }^{\circ} \mathrm{C}$. This is followed by Jain et al.[11] demonstrating the scaling up the active area of YSZ electrolyte-supported cells to $4 \mathrm{~cm}^{2}$. The results also demonstrated that pyrolyzed medium density fibreboard (pMDF) was a promising fuel for HDCFC,

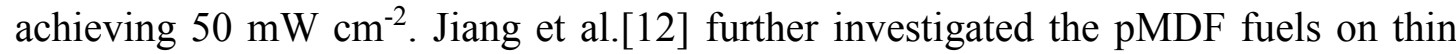
$(5 \mu \mathrm{m})$ YSZ electrolyte which produced the highest power density of $878 \mathrm{mWcm}^{-2}$ using lanthanum doped strontium cobalt (LSC) cathode. The excellent electrochemical performance was ascribed to lower ohmic and polarization resistance, less carbonate blocking at the gas/liquid/solid interfaces, faster gas diffusion and transportation, good cathode catalyst and flowing air at the cathode. Recently Elleuch et al.[13] showed the origin of $\mathrm{CO}, \mathrm{H}_{2}$ and $\mathrm{CH}_{4}$ in the anode from complex chain chemical reactions of surface oxygen groups in olive wood charcoal and thus obtained a maximum power density of $105 \mathrm{mWcm}^{-2}$ at $700{ }^{\circ} \mathrm{C}$. In recent research Hao et al.[14] evaluated magazine and newspaper waste papers carbon in HDCFCs. The cell fed with magazine waste paper carbon exhibited a higher performance with a peak power density of $172 \mathrm{mWcm}^{-}$ ${ }^{2}$ at $650{ }^{\circ} \mathrm{C}$. From these previous literature, biomass is supposed to be a promising fuel in hybrid DCFCs. Large amounts of organic groups in biomass at operating temperature emit fuel gas such as $\mathrm{H}_{2}, \mathrm{CO}$ and $\mathrm{CH}_{4}$, which is primarily contributed to the enhanced performance in DCFCs. However, the understanding of complex reaction in the anode compartment and mechanism of alkali metal carbonate catalytic effects lag behind the 
cell performance development.

In this study, sawdust selected as biofuels including sieved and pyrolyzed sawdust has been investigated in hybrid direct carbon fuel cells. Based on the structural and thermal characterizations of sieved sawdust and pyrolyzed sawdust, the comparative electrochemical performance with various mass ratios of carbon-carbonate mixture is optimized. Associated with off-gas evolution measured in flowing $\mathrm{N}_{2}$ and $\mathrm{CO}_{2}$ analyzed by gas chromatography, a deep insight into different reaction mechanisms is discussed to interpret the enhanced performance of two fuels. Furthermore, reasonable and modified mechanisms for catalytic properties of alkali metal carbonate in accelerating carbon gasification process in $\mathrm{N}_{2}$ and $\mathrm{CO}_{2}$ flowing are suggested.

\section{Experimental}

\subsection{Preparation of sawdust fuels}

The sawdust biomass used in this study was collected from wood processing workshop. To ensure the homogeneity of physical properties and reduce particle size, the raw sawdust was passed through 80 mesh sieve $(180 \mu \mathrm{m})$. Then the sieved powders were pyrolyzed in tube furnace under flowing $\mathrm{N}_{2}$ gas at $400{ }^{\circ} \mathrm{C}$ for $2 \mathrm{~h}$. The average yield of the pyrolyzed sawdust calculated over 5 batches was $30.4 \%$ as indicated in Table 1 . The acquired carbon fuels including sieved and pyrolyzed sawdust mixed with different weight ratios of lithium-potassium carbonate eutectic $\left(62 \mathrm{~mol}_{0} \mathrm{Li}_{2} \mathrm{CO}_{3}-\right.$ $38 \mathrm{~mol} \% \mathrm{~K}_{2} \mathrm{CO}_{3}$ ) were prepared as fuels for the cell performance test.

Table 1

Summarized results of sawdust pyrolysis.

\begin{tabular}{llll}
\hline Number & Sawdust/g & Pyrolyzed sawdust $/ \mathrm{g}$ & Yield $/ \%$ \\
\hline
\end{tabular}




\begin{tabular}{llll}
\hline 1 & 1.72 & 0.50 & 29.07 \\
2 & 2.37 & 0.72 & 30.38 \\
3 & 3.27 & 0.98 & 29.97 \\
4 & 5.97 & 1.81 & 30.32 \\
5 & 6.64 & 2.15 & 32.38 \\
\hline
\end{tabular}

\subsection{Characterization of sawdust fuels}

The physicochemical properties of the sawdust are the key parameters to determine the cell performance. The X-ray diffraction patterns of the prepared samples were obtained by PANalytical X'Pert ( $\mathrm{Cu}$ K $\alpha$ radiation). The morphology was examined via Scanning Electron Microscope (JSM-5600, Jeol). The thermal behaviors of carbon fuels evaluated by Thermo-gravimetric analysis (TGA) using a Thermo-gravimetric Analyzer (Netzsch-209). The TGA data was collected under $\mathrm{N}_{2}$ or air atmosphere with a heating rate of $5{ }^{\circ} \mathrm{C} \mathrm{min}^{-1}$ from room temperature to $800{ }^{\circ} \mathrm{C}$.

During cell testing, the gas products were analyzed on an Agilent 3000 micro Gas Chromatograph equipped with two capillary columns and a backflush injector. The thermal conductivity detector (TCD) was calibrated by a standard gas mixture of $\mathrm{H}_{2}$, $\mathrm{CH}_{4}, \mathrm{CO}, \mathrm{CO}_{2}$ balance $\mathrm{He}$, and also $\mathrm{N}_{2}$ and air. All off-gas products were measured in the same condition.

\subsection{Cell Fabrication and performance test}

$10 \times 10 \mathrm{~cm}$ anode supported half-cells were prepared by tape casting to form a porous $\mathrm{Ni} / \mathrm{YSZ}$ scaffold $(415 \mu \mathrm{m})$ with black carbon as pore former, a Ni/YSZ active layer (15 $\mu \mathrm{m})$ and a dense YSZ electrolyte $(17 \mu \mathrm{m})$. These were laminated and co-sintered at $1400{ }^{\circ} \mathrm{C}$ for $4 \mathrm{~h}$ in air. Then the obtained half-cells were laser cut into smaller $2.5 \mathrm{~cm}$ diameters button cells. A GDC interlayer $(2 \mu \mathrm{m})$ was then coated onto the YSZ 
electrolyte by dip-coating and sintering at $1200^{\circ} \mathrm{C}$ for $2 \mathrm{~h}$, to prevent reactions between the YSZ electrolyte and the GDC/LSCF composite cathode. The GDC/LSCF composite cathode $(25 \mu \mathrm{m})$ and LSCF current collection layer $(25 \mu \mathrm{m})$ was screen printed on the surface of the thin GDC interlayer with $1.1 \mathrm{~cm}$ in diameter, co-calcined at $1050{ }^{\circ} \mathrm{C}$ for $4 \mathrm{~h}$. The schematic diagram of HDCFC design and the SEM image of the cross-section of the anode-supported cell are shown in Fig.1.
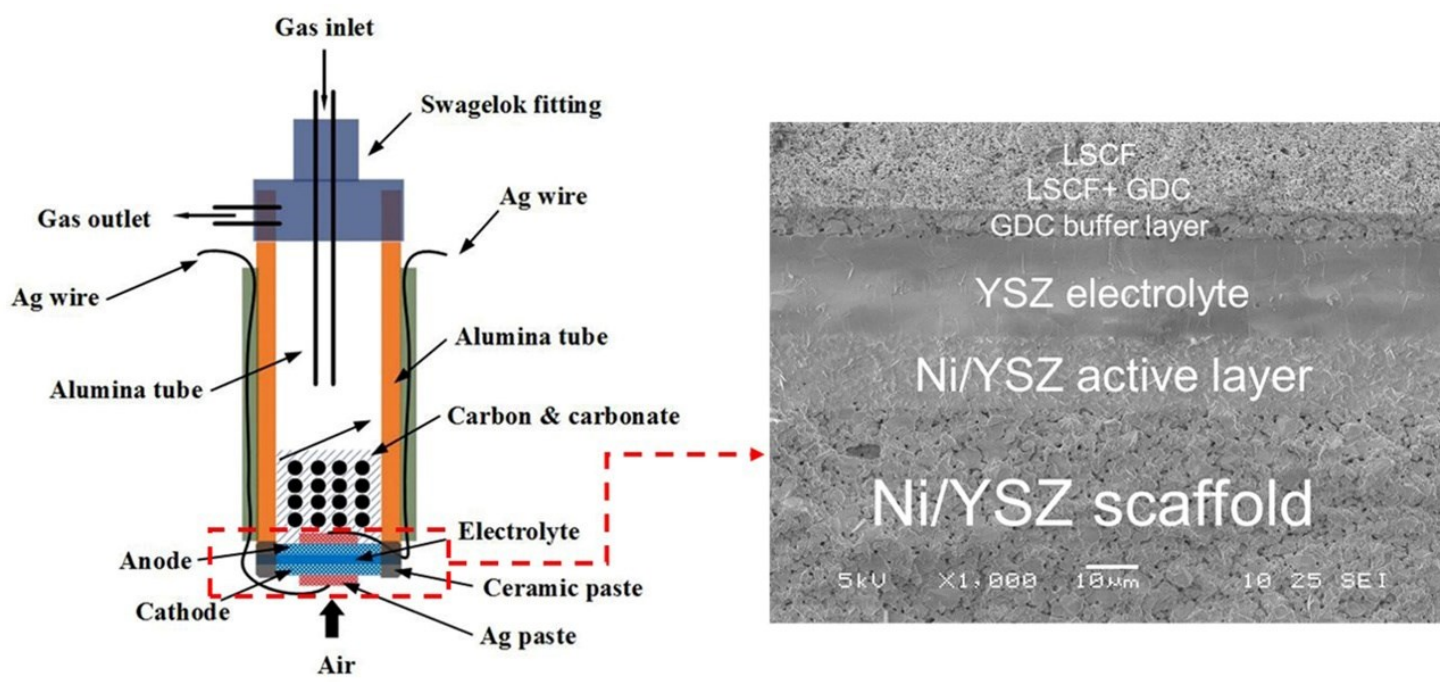

Fig.1.The schematic diagram of HDCFC design and the SEM image of the cross-section of the anode-supported cell.

Before electrochemical measurements, silver paste was painted on each electrode surface as the current collector and the cells were sealed into the jig. During the heating operation the anode chamber was purged under $\mathrm{N}_{2}$ at $10 \mathrm{ml} \mathrm{min}^{-1}$ as inert gas, while the cathode side was exposed to the ambient air. When the cell was ramping to the operating temperature $\left(750{ }^{\circ} \mathrm{C}\right)$, the flow rate was exchanged into $20 \mathrm{ml} \mathrm{min}^{-1}$. The current density-voltage(I-V) curves were tested by an IM6 Electrochemical Workstation (ZAHNER, Germany) with four-probe configuration, described as previous work[8].

\section{Results and discussion}

\subsection{Structural and thermal characterization}


The XRD patterns of sieved and pyrolyzed sawdust are presented in Fig. 2. The pattern of sieved sawdust demonstrates characteristic wide reflections of the cellulose I crystalline phase[15]. The cellulose polymer is composed of ringed glucose units $\left(\mathrm{C}_{6} \mathrm{H}_{10} \mathrm{O}_{5}\right)_{n}$, as indicated with the insert graph. No traces of crystalline mineral impurities were detected in sawdust. The broad diffraction peak (002) and another weak peak (001) in XRD pattern of pyrolyzed sawdust reveal that the amorphous carbon structure is formed after pyrolysis treatment at $400{ }^{\circ} \mathrm{C}$.

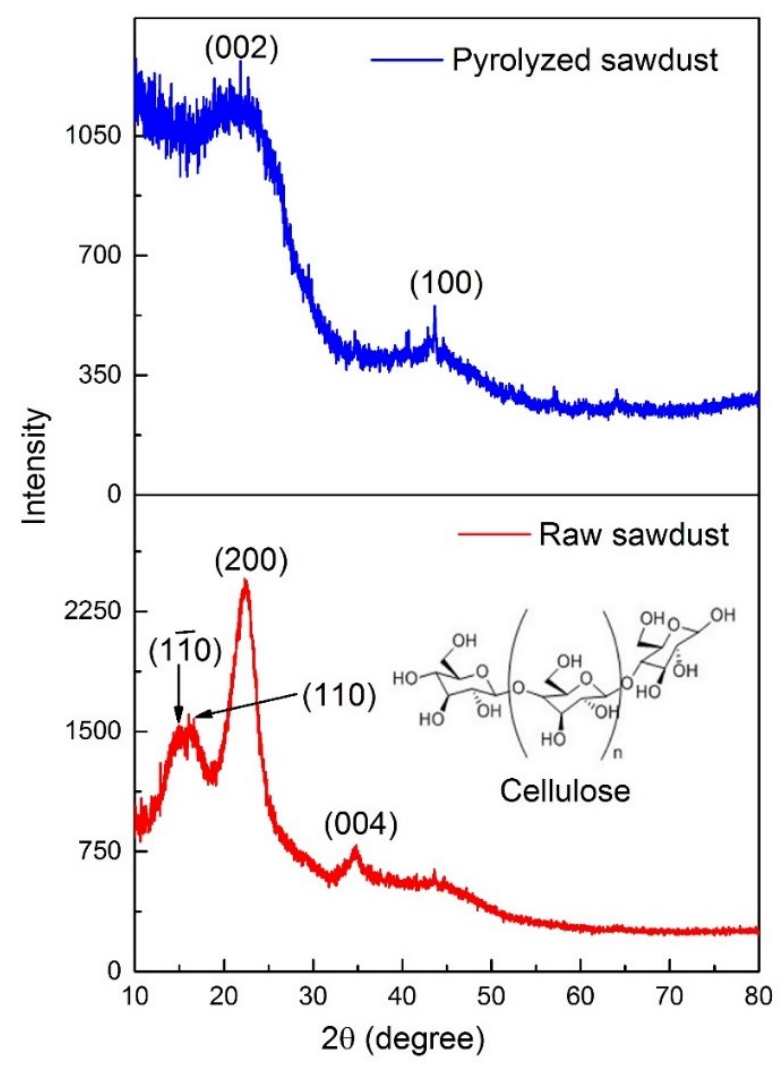

Fig. 2. The XRD patterns of sawdust and pyrolyzed sawdust.

The thermal reactivity for various samples was investigated by thermogravimetric analysis (TGA) in this study, providing the simulation of pyrolysis of carbonaceous composition evolution during the heating segment, especially for sawdust pyrolysis in situ in HDCFCs, as shown in Fig. 3. The carbonate medium seems to be stable until the 
operating temperature $\left(750{ }^{\circ} \mathrm{C}\right)$ and the overall weight loss is about $20 \mathrm{wt} \%$ to $800{ }^{\circ} \mathrm{C}$. The small mass loss except for sawdust before $150{ }^{\circ} \mathrm{C}$ can be ascribed to moisture evaporation. It can be confirmed that the moisture is primarily originated from lithiumpotassium carbonate due to its water-absorbing behavior in ambient air. For pyrolyzed sawdust and carbonate \& pyrolyzed sawdust samples, both of them present a similar weight loss profile under $\mathrm{N}_{2}$ until $749^{\circ} \mathrm{C}$, where the mass of the carbonate \& pyrolyzed sawdust sample starts to decrease because of the carbonate decomposing at higher temperature. Fig. 3(b) shows typical curves for thermal degradation of lignocellulose materials exposed to air atmosphere, followed by two distinct peaks observed in DTG curves at around 325 and $460{ }^{\circ} \mathrm{C}$. The first pronounced weight loss, initiating at around $220{ }^{\circ} \mathrm{C}$ and ending $350{ }^{\circ} \mathrm{C}$, corresponds to a devolatilization process, in which the scission of polymeric chains to separate cellulose, making the liquid phase formation. Then with the temperature ramping, the liquid phase reaches the ebullition point and interacts with the solid phase. A further weight loss occurs in the temperature range of 350 and $500{ }^{\circ} \mathrm{C}$, which is assigned to a char combustion stage. In this process, the main species are released, such as hydroxyacetaldehyde, glyoxal, water, 5-hydroxymethylfurfural, methanol, carbon monoxide and carbon dioxide. Compared to sawdust in $\mathrm{N}_{2}$ atmosphere, the thermal decomposition of sawdust in air exhibits more sharply. This is because oxygen is known to enhance the decomposition of materials[16]. It can also be found that the remaining ash content of sawdust is very low $(0.8 \mathrm{wt} \%)$, which is in accordance with the XRD results. 

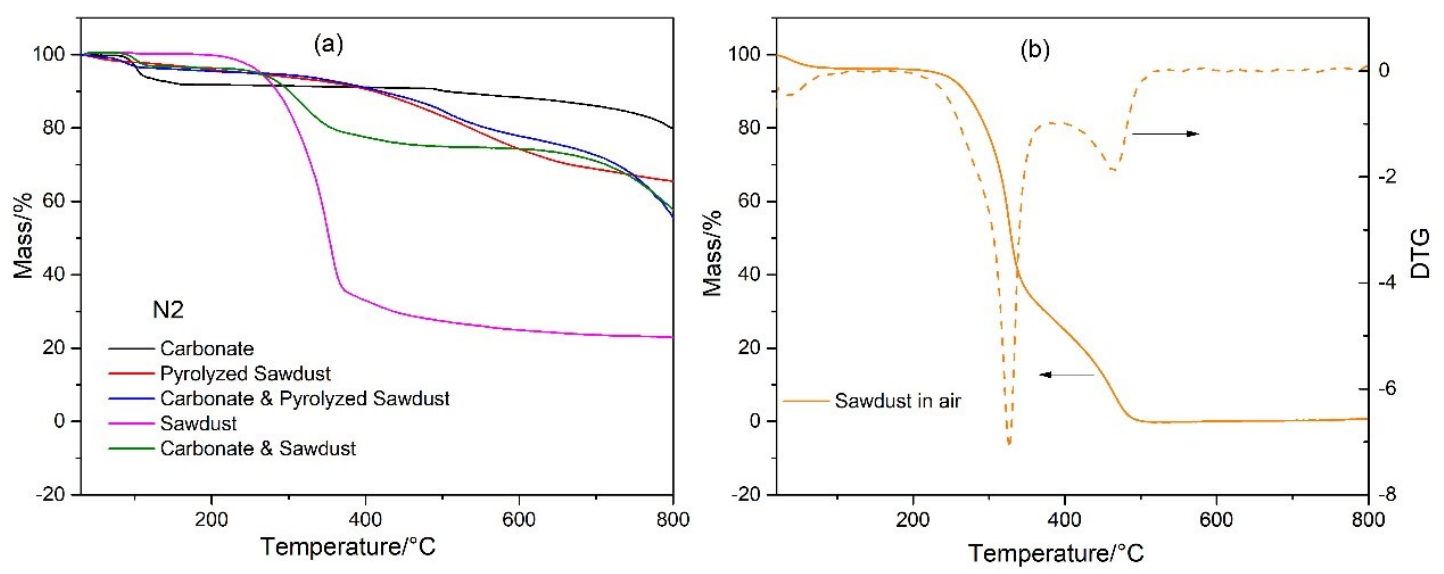

Fig. 3. TGA and DTG profiles of different samples (The weight ratio of biomass and carbonate is 1:1): (a) in $\mathrm{N}_{2}$ atmosphere; (b) exposed to air.

\subsection{Electrochemical performance and analysis}

To optimize the electrochemical performance of the sieved and pyrolyzed sawdust, different mass ratios of carbon tocarbonate were investigated by I-V-P measurement in $\mathrm{CO}_{2}$ flow, as shown in Fig. 4. In Fig. 4(a), the open circuit voltages (OCV) for pyrolyzed sawdust with $40 \mathrm{wt} \%, 50 \mathrm{wt} \%, 60 \mathrm{wt} \%$ and $80 \mathrm{wt} \%$ carbon contents are $1.002,1.022$, $1.009,0.99$ and $1.002 \mathrm{~V}$, respectively. This indicates that the changing carbonate content doesn't significantly influence OCV values. In Fig. 4(b), the measured OCVs of 20 $\mathrm{wt} \%, 50 \mathrm{wt} \%, 60 \mathrm{wt} \%$ and $80 \mathrm{wt} \%$ sawdust fuels are $0.966 \mathrm{~V}, 0.992 \mathrm{~V}, 0.991 \mathrm{~V}$ and $0.995 \mathrm{~V}$, respectively. They are slightly lower than that of pyrolyzed sawdust fuels due to gas composition changes in anode chamber.

The $50 \mathrm{wt} \%$ pyrolyzed sawdust show a maximal power density of $731 \mathrm{mWcm}^{-2}$ at $750{ }^{\circ} \mathrm{C}$. Whereas the maximum power density of sieved sawdust has highest for the 20 $\mathrm{wt} \%$ carbon proportion at $789 \mathrm{mWcm}^{-2}$, appearing to be superior to $50 \mathrm{wt} \%$ carbon loading of pyrolyzed sawdust. It should be noted that even though the outstanding performance is observed in large proportion of carbonate for sieved sawdust, the corrosive behavior of carbonate on the scaffold structure cannot be evitable and it will [在此处键入] 
be detrimental to the cell stability significantly.
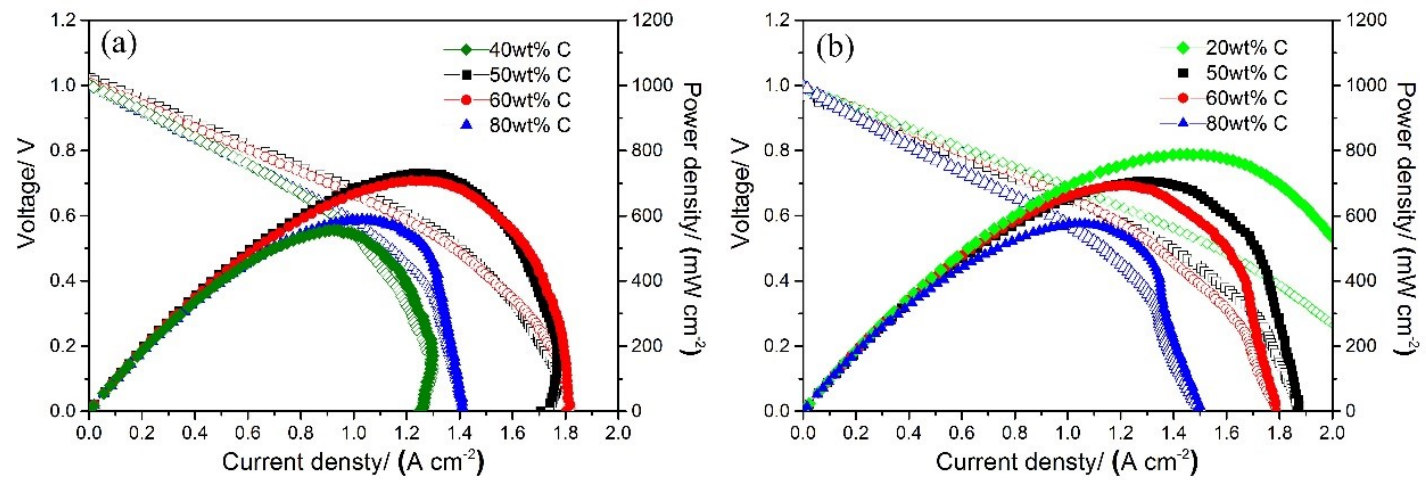

Fig. 4. I-V-P curves of different mass ratios of the carbon-carbonate mixture acquired in $\mathrm{CO}_{2}$ flow at $750{ }^{\circ} \mathrm{C}$ : (a) pyrolyzed sawdust, (b) sieved sawdust.

Despite the good power density is obtained in $\mathrm{CO}_{2}$ flow, the aim for the hybrid direct carbon fuel cell design is produce, capture and store high concentration $\mathrm{CO}_{2}$ offgas. Fig.5 shows I-V-P curves of the two fuels as function of weight ratios of the carboncarbonate mixture measured under $\mathrm{N}_{2}$ flow at $750{ }^{\circ} \mathrm{C}$. The $\mathrm{OCV}$ values are around 1.1 $\mathrm{V}$ for the cells in $\mathrm{N}_{2}$ purge gas, which is about $0.1 \mathrm{~V}$ higher than that of values in $\mathrm{CO}_{2}$ gas, as expected when lowering the product gas concentration in the cell. It also can be seen that the high current region of the I-V-P curves shows a steeper drop off than those of $\mathrm{CO}_{2}$ flow which may be due to a change in reaction mechanism or the unstable periodic reaction rate at certain operating voltages explained by other researchers $[17$, 18]. The changing trend of the maximum power density of pyrolyzed sawdust in $\mathrm{N}_{2}$ has similar features to that in $\mathrm{CO}_{2}$ as presented in Fig. 5(a). With carbon weight ratios of $40 \mathrm{wt} \%, 50 \mathrm{wt} \%, 60 \mathrm{wt} \%$ and $80 \mathrm{wt} \%$, the maximum power density of pyrolyzed sawdust are $306,388,384$, and $344 \mathrm{mWcm}^{-2}$, respectively. It seems that the variable carbonate proportion has little effect on the power output in $\mathrm{N}_{2}$ flow. In contrast, the sieved sawdust with carbon loading of $20 \mathrm{wt} \%$ and $50 \mathrm{wt} \%$ have nearly same maximum power with the values of 605 and $610 \mathrm{mWcm}^{-2}$ among the selected carbon-carbonate [在此处键入] 
mixture shown in Fig. 5(b). The maximum power density of $60 \mathrm{wt} \%$ and $80 \mathrm{wt} \%$ sawdust proportions are only 355 , and $320 \mathrm{mWcm}^{-2}$, respectively. The sieved sawdust shows better performance than the pyrolyzed ones in certain mass ratios of carbon-carbonate mixture indicating that sawdust without pyrolysis is supposed to be promising feedstock in carbon fuel cells.
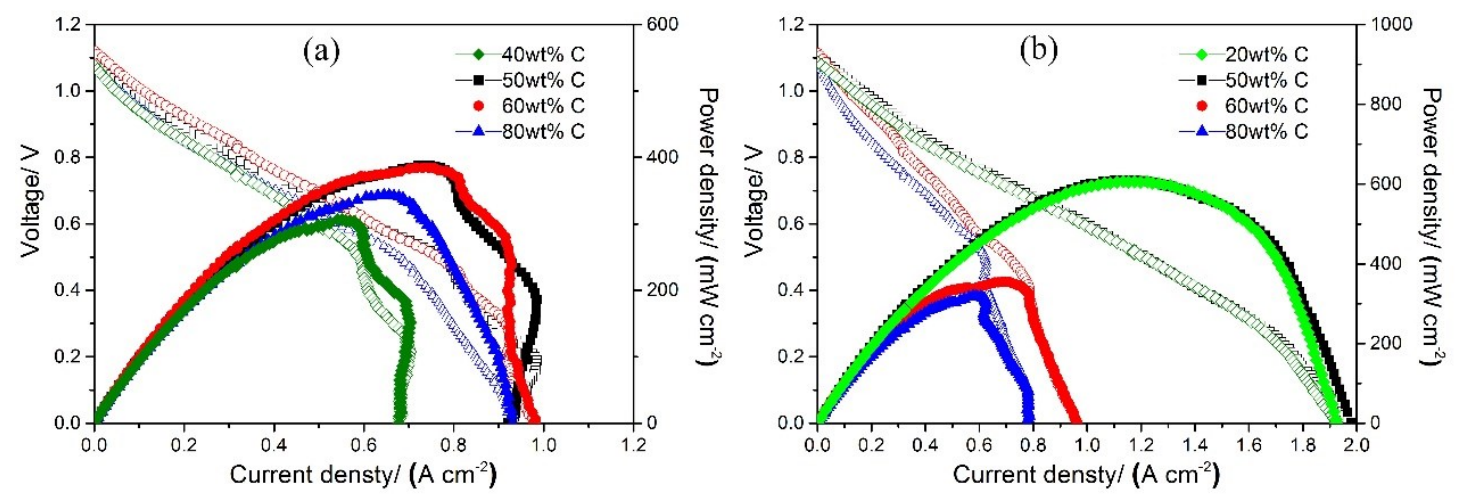

Fig. 5. I-V-P curves of different mass ratios of the carbon-carbonate mixture acquired in $\mathrm{N}_{2}$ flow at $750^{\circ} \mathrm{C}$ : (a) pyrolyzed sawdust, (b) sieved sawdust.

Fig. 6 compares the EIS for pyrolyzed and sieved sawdust in $\mathrm{CO}_{2}$ flow at $750{ }^{\circ} \mathrm{C}$. The lowest ohmic and polarization values confirm the superior performance for $20 \mathrm{wt} \%$ sawdust in $\mathrm{CO}_{2}$ flow. However, for pyrolyzed sawdust in $\mathrm{CO}_{2}$ and $\mathrm{N}_{2}$ flow, even though the lowest ohmic resistance is obtained for $60 \mathrm{wt} \%$ pyrolyzed sawdust loading, the $50 \mathrm{wt} \%$ loading show a slightly higher performance due to the lower polarization value. That means the dominated resistance originates from polarization contribution. From the behavior of optimizing carbon-carbonate weight ratios in the impedance spectra, there is no doubt that the polarization evolution is mainly associated with anode contribution. Because the Ni/YSZ supported anode with LSCF cathode fueled $\mathrm{H}_{2}$ yields a $\mathrm{R}_{P}$ value of $0.047 \Omega \mathrm{cm}^{2}$ at $750{ }^{\circ} \mathrm{C}[19]$. As for both sawdust in $\mathrm{CO}_{2}$ (Fig. 6(a) and (b)), coupled with Fig. 4, the cells with poor performance possesses a larger length of high frequency 
arc in polarization part, but the low frequency arc is similar to other weigh ratios without visible increase. However, the shape of impendence spectra in $\mathrm{N}_{2}$ is somewhat different from that in $\mathrm{CO}_{2}$. The change of purge gas from $\mathrm{CO}_{2}$ to $\mathrm{N}_{2}$ results in a remarked increase in low frequency arc. It has been reported that the higher frequency arc region is related to the charge transfer process, while the lower frequency arc region to gas adsorption/desorption or surface diffusion process[20]. Tuning carbon-carbonate weight ratios may change the reaction mechanism or reaction kinetic rate resulting in variational length in higher frequency arc. Furthermore, the purged $\mathrm{CO}_{2}$ gas involved in complex anode reaction will improve mass transfer resistance, thus reducing the lower frequency arc. In addition, the distinct features on the cell performance trend of sawdust between $\mathrm{N}_{2}$ and $\mathrm{CO}_{2}$ conditions indicates the differing dominant chemical and electrochemical reactions. The gas chromatography will be used to assess which gas composition rendering active electrochemical oxidation contribution. 

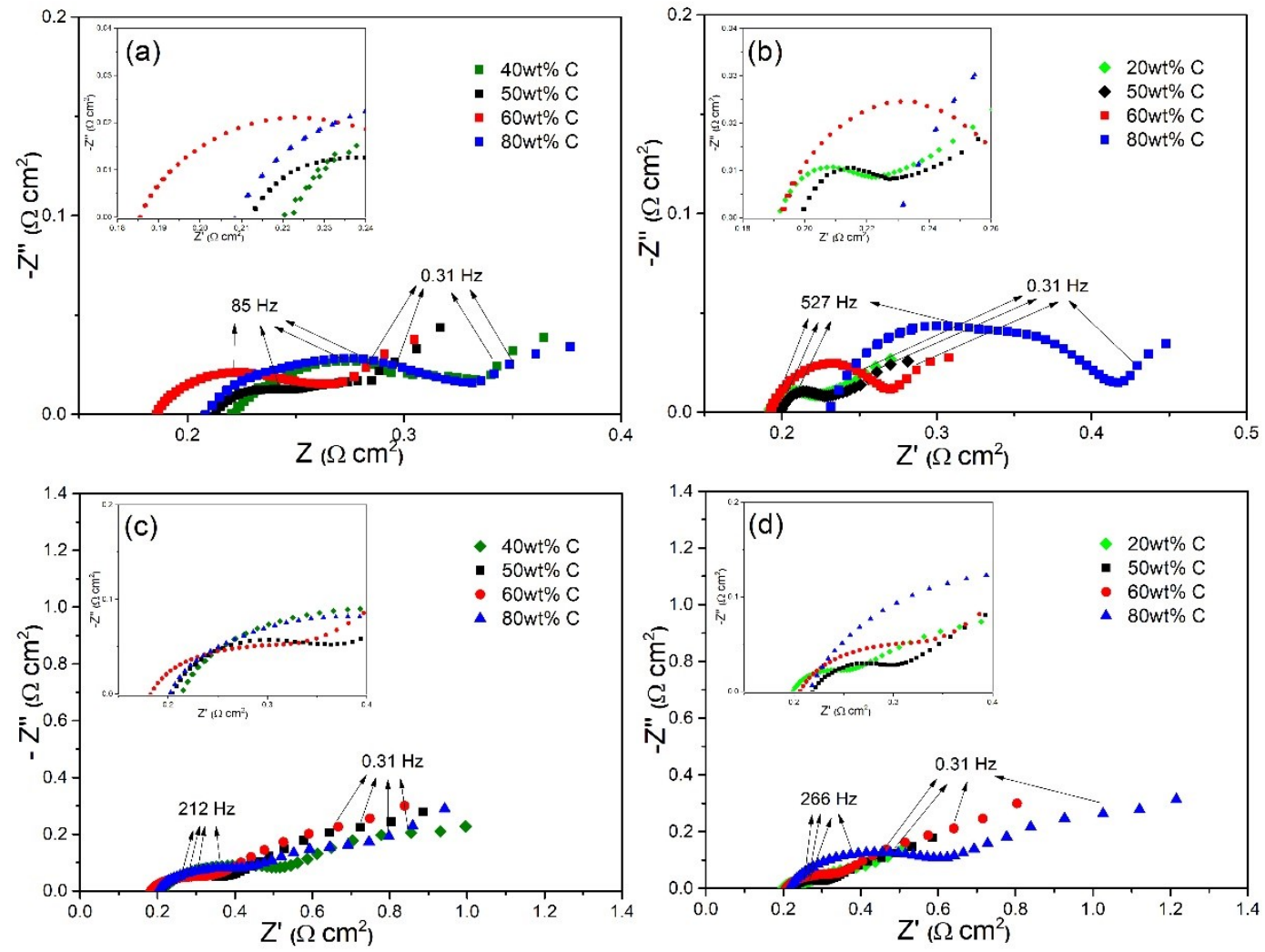

Fig. 6. The impedance spectra of different mass ratios of the carbon-carbonate mixture obtained under open circuit at $750^{\circ} \mathrm{C}$ : (a) pyrolyzed sawdust in $\mathrm{CO}_{2}$, (b) sieved sawdust in $\mathrm{CO}_{2}$, (a) pyrolyzed sawdust in $\mathrm{N}_{2}$ and sieved sawdust in $\mathrm{N}_{2}$.

It has been suggested that the electrochemical oxidation of $\mathrm{CO}$ (Eq. (1)) from the Boudouard reaction via Eq. (2) is the predominant reaction mechanism in solid oxide electrolyte carbon fuel cell $[9,21]$. Thus, the possibility of direct carbon electrochemical oxidation in Eq. (3) is difficult since solid carbon only at the triple phase boundary (TBP) exhibits reaction reactivity [22]. The addition of alkali carbonate (Li, Na, $\mathrm{K}$ and etc.) not only extends the contact between solid carbon and TBP, but also catalyzes the carbonaceous materials yielding more $\mathrm{CO}$ and other fuel gas.

$$
\begin{aligned}
& \mathrm{CO}+\mathrm{O}^{2-} \rightarrow \mathrm{CO}_{2}+2 \mathrm{e}^{-} \\
& \mathrm{C}+\mathrm{CO}_{2} \rightarrow 2 \mathrm{CO} \\
& \mathrm{C}+2 \mathrm{O}^{2-} \rightarrow \mathrm{CO}_{2}+4 \mathrm{e}^{-}
\end{aligned}
$$

The anode off-gas was analyzed by a gas chromatography to investigate the [在此处键入] 
complex anodic reactions and the carbonate catalytic effects. The temperature dependence of the effluent gas composition from virous cells is shown in Fig. 7. In case of pyrolyzed sawdust in $\mathrm{N}_{2}$ flow, only $\mathrm{CO}, \mathrm{CO}_{2}$, and small traces of $\mathrm{CH}_{4}$ gases are detected. With the temperature increasing, the amount of $\mathrm{CO}$ formation increases due to the Boudouard reaction being favored above $700{ }^{\circ} \mathrm{C}$. When $\mathrm{CO}_{2}$ gas was introduced to the anode chamber, the amount of both $\mathrm{CO}$ and $\mathrm{CO}_{2}$ increase incredibly and the $\mathrm{CH}_{4}$ gas disappears(Fig.7 (b)). The addition of $\mathrm{CO}_{2}$ can promote the $\mathrm{CO}$ production via the Boudouard reaction and raise the electrochemical reaction rate, which is in line with the enhanced performance in Fig.4 (b). When feedstock is exchanged to sawdust shown in Fig.7 (c) and Fig.7 (d), a large amount of other gases springs are present. (Because these gas products are not internal standardized in chromatography, they are referred to "other gas".) The existence of other gas demonstrates that the $\mathrm{CO}$ electro-oxidation are not dominant reaction mechanism in power generation. When the sawdust as fuel feedstock is directly filled into alumina tube, the sawdust will pyrolyze in situ during the heating process. The carbon-oxygen functional groups (carboxyl, lactone, phenol, carbonyl, anhydride and etc.) are dissociated in the first stage, then these carbon-oxygen functional groups from lignocellulose structure release $\mathrm{CO}, \mathrm{CO}_{2}, \mathrm{CH}_{4}, \mathrm{H}_{2}$, and dissociate into some traces of light hydrocarbons (mainly including $\mathrm{C}_{2} \mathrm{H}_{4}, \mathrm{C}_{2} \mathrm{H}_{6}, \mathrm{C}_{3} \mathrm{H}_{6}$, $\mathrm{C}_{3} \mathrm{H}_{8}$, and $\left.\mathrm{n}-\mathrm{C}_{4} \mathrm{H}_{10}\right)[13,23]$. Except for small contribution of $\mathrm{CO}$ electro-oxidation via Eq. (1), the liquid and gaseous hydrocarbon electrochemical oxidation mainly account for the enhanced power output in Eq. (4). Indeed, the amount of other gas is several folds than $\mathrm{CO}$ in $\mathrm{N}_{2}$ condition. That's why the cell performance results of sieved 
sawdust differ considerably from pyrolyzed sawdust. When introducing $\mathrm{CO}_{2}$ gas, the amount of producing $\mathrm{CO}$ fueled sawdust can be parallel to the magnitude of $\mathrm{CO}$ generated from pyrolysis samples, but the extra fuel will be provided in sawdust feedstock.

$$
\mathrm{C}_{\mathrm{x}} \mathrm{H}_{\mathrm{y}}+(2 \mathrm{x}+\mathrm{y} / 2) \mathrm{O}^{2-} \rightarrow \mathrm{xCO}_{2}+\mathrm{y} / 2 \mathrm{H}_{2} \mathrm{O}+(4 \mathrm{x}+\mathrm{y}) \mathrm{e}^{-}
$$
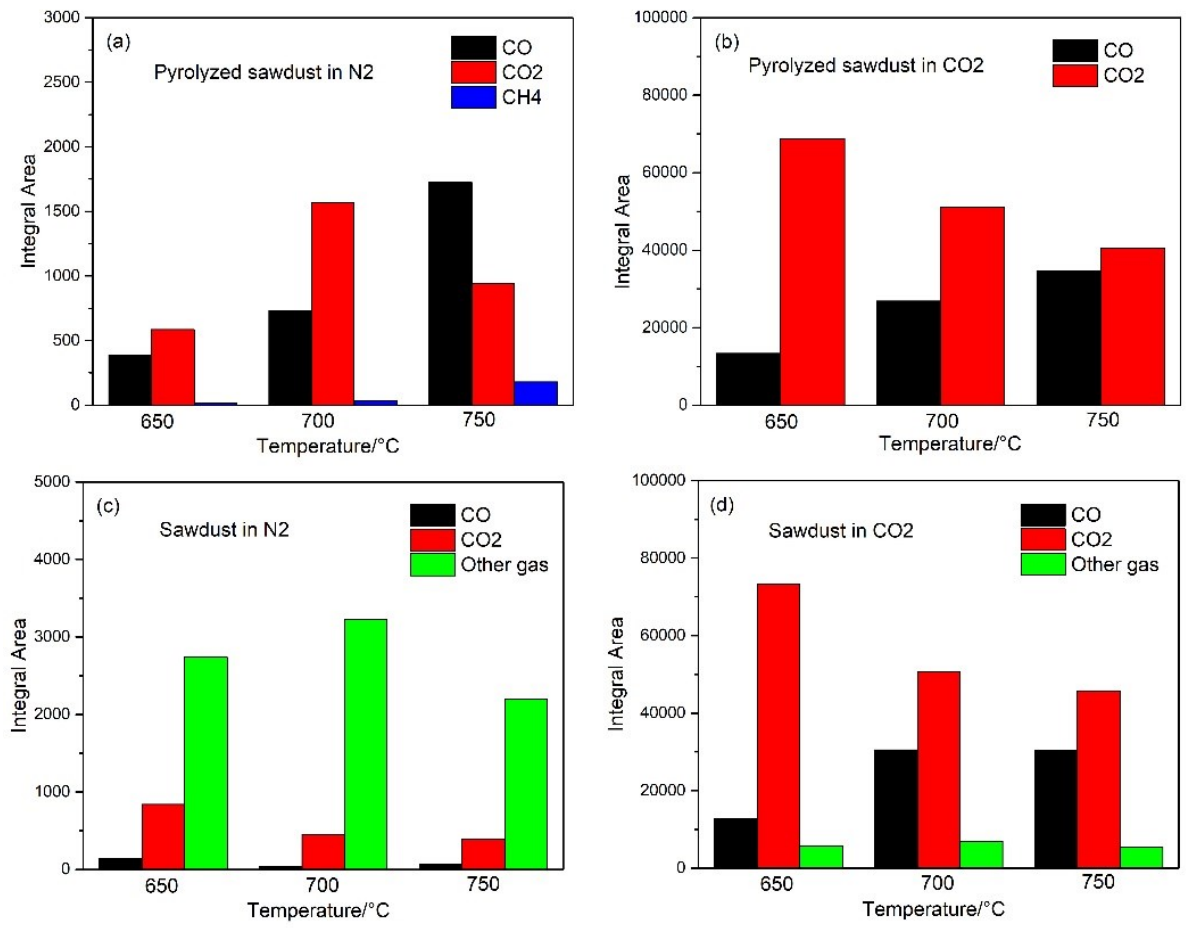

Fig. 7. The observed composition of anode off-gas as a function of the temperature. (The mass ratio of carbon feedstock and carbonate is 1:1,2g. Other gas contains $\mathrm{CH}_{4}, \mathrm{H}_{2}$ and other gas which has no standard gas in Chromatography) 


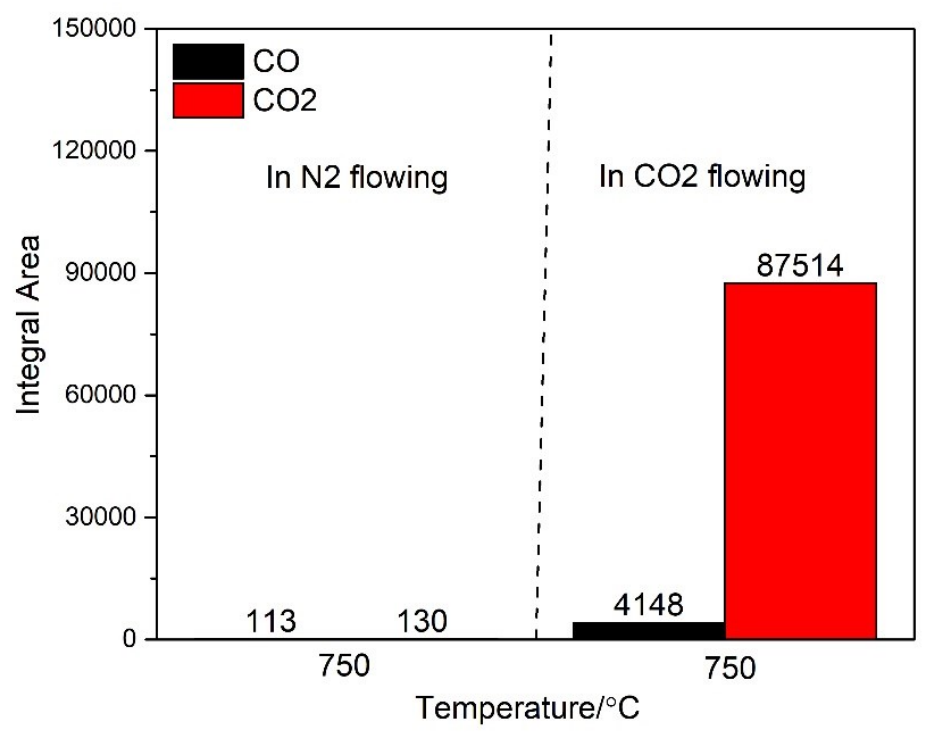

Fig. 8. Gas products composition of pyrolyzed sawdust in absence of carbonate measured by $\mathrm{GC}$ at $750^{\circ} \mathrm{C}$. (The mass of pyrolyzed sawdust is $1 \mathrm{~g}$.)

For comparison purpose, Fig. 8 presents the gas products content of pyrolyzed sawdust in the absence of carbonate measured at $750{ }^{\circ} \mathrm{C}$. As a result, the addition of $\mathrm{Li}$, $\mathrm{K}$ eutectic carbonates promotes a considerable increase in the gasification reaction by several orders of magnitude. So far, many detailed investigations have been carried out to demonstrate that the kinetics of gasification reactions of carbonaceous materials with $\mathrm{CO}_{2}$ and steam were strongly enhanced by the incorporation of alkali metal carbonates and oxides such as $\mathrm{Li}_{2} \mathrm{CO}_{3}$ and $\mathrm{K}_{2} \mathrm{CO}_{3}$ [24-26]. The oxygen-reduction cycle mechanisms that have been proposed to explain their catalytic behaviors in carbon gasification process can be classified as lower oxide $\rightarrow$ higher oxide $\rightarrow$ lower oxide cycle and metal $\rightarrow$ oxide $\rightarrow$ metal cycle types $[27,28]$.

When the carbon-carbonate mixture was heated in $\mathrm{O}_{2}$ flow, the metal oxide $\left(\mathrm{M}_{2} \mathrm{O}\right)$ was formed by thermal dissociation. Then the initially formed $\mathrm{M}_{2} \mathrm{O}$ would reoxidize to peroxide $\left(\mathrm{M}_{2} \mathrm{O}_{2}\right)$ or higher oxide $\left(\mathrm{M}_{2} \mathrm{O}_{3} \mathrm{M}_{2} \mathrm{O}_{4}\right)$. The $\mathrm{M}_{2} \mathrm{O}$ was reproduced as a result of 
reduction reaction:

$$
\begin{aligned}
& \mathrm{M}_{2} \mathrm{CO}_{3}+\mathrm{C}+\mathrm{O}_{2} \rightarrow \mathrm{M}_{2} \mathrm{O}+2 \mathrm{CO}_{2} \\
& \mathrm{M}_{2} \mathrm{O}+\mathrm{n} / 2 \mathrm{O}_{2} \rightarrow \mathrm{M}_{2} \mathrm{O}_{1+\mathrm{n}} \\
& \mathrm{M}_{2} \mathrm{O}_{1+\mathrm{n}}+\mathrm{nC} \rightarrow \mathrm{M}_{2} \mathrm{O}+\mathrm{nCO}
\end{aligned}
$$

However, the carbon-carbonate mixture is heated in $\mathrm{N}_{2}$ atmosphere in HDCFCs, and no $\mathrm{O}_{2}$ gas exists in the anode chamber. It should be considered that $\mathrm{O}^{2-}$ actually migrating from cathode replace with $\mathrm{O}_{2}$, which also provides the driving force to the decomposition process. Thus, a plausible oxidation-reduction cycle is following below:

$$
\begin{gathered}
\mathrm{M}_{2} \mathrm{CO}_{3}+\mathrm{C}+2 \mathrm{O}^{2-} \rightarrow \mathrm{M}_{2} \mathrm{O}+2 \mathrm{CO}_{2}+4 \mathrm{e}^{-} \\
\text {Or } \mathrm{M}_{2} \mathrm{CO}_{3}+\mathrm{C}+\mathrm{O}^{2-} \rightarrow \mathrm{M}_{2} \mathrm{O}+\mathrm{CO}_{2}+\mathrm{CO}+2 \mathrm{e}^{-} \\
\mathrm{M}_{2} \mathrm{O}+\mathrm{nO}^{2-} \rightarrow \mathrm{M}_{2} \mathrm{O}_{1+\mathrm{n}}+2 \mathrm{ne}^{-} \\
\mathrm{M}_{2} \mathrm{O}_{1+\mathrm{n}}+\mathrm{nC} \rightarrow \mathrm{M}_{2} \mathrm{O}+\mathrm{nCO}
\end{gathered}
$$

When considering the alkali melt catalyzed the reaction in flowing $\mathrm{CO}_{2}$, the thermodynamic dissociation via Eq. (8) or (9) is not likely to be feasible due to the tough reaction of $\mathrm{M}_{2} \mathrm{O}$ to $\mathrm{M}_{2} \mathrm{CO}_{3}$ conversion. So metal $\rightarrow$ oxide $\rightarrow$ metal cycle has been suggested to explain the effect of alkali metal carbonates in $\mathrm{CO}_{2}$ atmosphere:

$$
\begin{gathered}
\mathrm{M}_{2} \mathrm{CO}_{3}+2 \mathrm{C} \rightarrow 2 \mathrm{M}+3 \mathrm{CO} \\
2 \mathrm{M}+3 \mathrm{CO}_{2} \rightarrow \mathrm{M}_{2} \mathrm{O}+\mathrm{CO} \\
\mathrm{M}_{2} \mathrm{O}+\mathrm{CO}_{2} \rightarrow \mathrm{M}_{2} \mathrm{CO}_{3}
\end{gathered}
$$

Combining Reaction (13) and (14), the overall reaction is the Boudouard reaction (Eq. (2)), whereas the $\mathrm{Li}_{2} \mathrm{CO}_{3}$ and $\mathrm{K}_{2} \mathrm{CO}_{3}$ eutectic salts exhibit the catalytic media promoting more $\mathrm{CO}$ products formation, which is in good agreement with enhanced 
performance in $\mathrm{CO}_{2}$ atmosphere. It has been evidenced that the presence of alkali metal salts acting as reactive sites for oxygen chemisorption lead to the weakening of C-C bonds and strengthening of C-O bonds during oxidation. Nevertheless, Reaction (12) is unfavorable for $\mathrm{Li}_{2} \mathrm{CO}_{3}$ in this condition[29]. Maybe the formation of $\mathrm{Li}_{2} \mathrm{O}$ is directly generated through the following cycles:

$$
\begin{aligned}
& \mathrm{M}_{2} \mathrm{CO}_{3}+2 \mathrm{C} \rightarrow \mathrm{M}_{2} \mathrm{O}+2 \mathrm{CO} \\
& \mathrm{M}_{2} \mathrm{O}+\mathrm{CO}_{2} \rightarrow \mathrm{M}_{2} \mathrm{CO}_{3}
\end{aligned}
$$

The preliminary results have shown that it is possible to operate biomass with little pretreatment on HDCFCs. Though the addition of lithium and potassium eutectic carbonate into SOFC anode compartment has been proved to promote the power density dramatically, the inherent corrosion of carbonate on structural changes of anode components, the deactivation of the catalyst, carbon deposition that actually exists in SOFC and other factors inevitably render degradation of HDCFCs lifetime severely. Furthermore, composition variations of the produced biogas dependent of impurity, carbonate proportion and operating temperature require accurate control to reduce high fluctuation of power output.

\section{Conclusion}

In this work, sieved sawdust both straight and pyrolyzed as fuel feedstock has been investigated in HDCFCs. The structure and thermal characterization of sieved sawdust indicates thatit has cellulose I phase with very low ash. After carbonization, the pyrolyzed sawdust is formed of amorphous carbon. The $20 \mathrm{wt} \%$ sawdust proportion in sawdust-carbonate mixture produced the highest peak power density of $789 \mathrm{mWcm}^{-2}$ 
in flowing $\mathrm{CO}_{2}$ and $605 \mathrm{mWcm}^{-2}$ in flowing $\mathrm{N}_{2}$ at $750{ }^{\circ} \mathrm{C}$, which is better performance than that of pyrolyzed sawdust. Based on GC results, apart from the contribution of CO electrochemical oxidation, $\mathrm{H}_{2}, \mathrm{CH}_{4}$ and other light hydrocarbons produced during the carbonization of sawdust in the heating segment account for the enhanced performance in sieved sawdust. Compared to the poor performance without carbonate presence, the oxygen-reduction cycle mechanisms are suggested to explain the catalytic effects of alkali metal carbonate in considerably improving performance, especially for catalytic mechanism modified in inert atmosphere. Therefore, the present work has shown that raw sawdust can be promising fuel feedstock in HDCFCs.

\section{Acknowledgement}

The authors gratefully acknowledge the financial support by the Royal Society of Edinburgh for a RSE BP Hutton Prize in Energy Innovation.

\section{References}

[1] Jayaraman K, Kok MV, Gokalp I. Thermogravimetric and mass spectrometric (TG-MS) analysis and kinetics of coal-biomass blends. Renew Energ. 2017;101:293-300.

[2] Bach QV, Chen WH. A comprehensive study on pyrolysis kinetics of microalgal biomass. Energ Convers Manage. 2017;131:109-16.

[3] Kong LJ, Xiong Y, Liu T, Tu YT, Tian SH, Sun LP, et al. Effect of fiber natures on the formation of "solid bridge' for preparing wood sawdust derived biomass pellet fuel. Fuel Process Technol. 2016;144:79-84.

[4] Cooper JF. Direct Conversion of Coal and Coal-Derived Carbon in Fuel Cells. 2004:375-85.

[5] Kawase M. Durability and robustness of tubular molten carbonate fuel cells. Journal of Power Sources. 2017;371:106-11.

[6] Jiang CR, Ma JJ, Corre G, Jain SL, Irvine JTS. Challenges in developing direct carbon fuel cells. Chemical Society Reviews. 2017;46:2889-912.

[7] Fuente-Cuesta A, Jiang C, Arenillas A, Irvine JTS. Role of coal characteristics in the electrochemical behaviour of hybrid direct carbon fuel cells. Energ Environ Sci. 2016;9:2868-80.

[8] Li SB, Pan WZ, Wang SR, Meng X, Jiang CR, Irvine JTS. Electrochemical performance of different carbon fuels on a hybrid direct carbon fuel cell. International Journal of Hydrogen Energy. 2017;42:16279-87.

[9] Deleebeeck L, Hansen KK. Hybrid direct carbon fuel cells and their reaction mechanisms-a 
review. Journal of Solid State Electrochemistry. 2014;18:861-82.

[10] Nabae Y, Pointon KD, Irvine JTS. Electrochemical oxidation of solid carbon in hybrid DCFC with solid oxide and molten carbonate binary electrolyte. Energ Environ Sci. 2008;1:148-55.

[11] Jain SL, Lakeman JB, Pointon KD, Marshall R, Irvine JTS. Electrochemical performance of a hybrid direct carbon fuel cell powered by pyrolysed MDF. Energ Environ Sci. 2009;2:687-93.

[12] Jiang CRM, J. J. Bonaccorso, A. D. Irvine, J. T. S. Demonstration of high power, direct conversion of waste-derived carbon in a hybrid direct carbon fuel cell. Energ Environ Sci. 2012;5:6973-80.

[13] Elleuch A, Halouani K, Li YD. Investigation of chemical and electrochemical reactions mechanisms in a direct carbon fuel cell using olive wood charcoal as sustainable fuel. Journal of Power Sources. 2015;281:350-61.

[14] Hao WB, Mi YL. Evaluation of waste paper as a source of carbon fuel for hybrid direct carbon fuel cells. Energy. 2016;107:122-30.

[15] Poletto M, Pistor V, Zattera AJ. Structural Characteristics and Thermal Properties of Native Cellulose. Cellulose - Fundamental Aspects. 2013:45-68.

[16] Orfao JJM, Antunes FJA, Figueiredo JL. Pyrolysis kinetics of lignocellulosic materials - three independent reactions model. Fuel. 1999;78:349-58.

[17] Deleebeeck L, Hansen KK. HDCFC Performance as a Function of Anode Atmosphere (N-2CO2). Journal of the Electrochemical Society. 2014;161:F33-F46.

[18] Shi YX, Li C, Cai NS. Experimental characterization and mechanistic modeling of carbon monoxide fueled solid oxide fuel cell. Journal of Power Sources. 2011;196:5526-37.

[19] Chen J, Liang F, Liu L, Jiang S, Chi B, Pu J, et al. Nano-structured (La, Sr)(Co, Fe)O3+YSZ composite cathodes for intermediate temperature solid oxide fuel cells. Journal of Power Sources. 2008;183:586-9.

[20] Zhou Y, Yuan C, Chen T, Meng X, Ye X, Li J, et al. Evaluation of Ni and Ni-Ce0.8Sm0.2O2- $\delta$ (SDC) impregnated 430L anodes for metal-supported solid oxide fuel cells. Journal of Power Sources. 2014;267:117-22.

[21] Kulkarni A, Giddey S, Badwal SPS. Electrochemical performance of ceria-gadolinia electrolyte based direct carbon fuel cells. Solid State Ionics. 2011;194:46-52.

[22] Li C, Shi YX, Cai NS. Effect of contact type between anode and carbonaceous fuels on direct carbon fuel cell reaction characteristics. Journal of Power Sources. 2011;196:4588-93.

[23] Yu Y, Yang Y, Cheng ZC, Blanco PH, Liu RH, Bridgwater AV, et al. Pyrolysis of Rice Husk and Corn Stalk in Auger Reactor. 1. Characterization of Char and Gas at Various Temperatures. Energy \& Fuels. 2016;30:10568-74.

[24] Mckee DW, Spiro CL, Kosky PG, Lamby EJ. Catalysis of Coal Char Gasification by AlkaliMetal Salts. Fuel. 1983;62:217-20.

[25] Mckee DW, Spiro CL, Kosky PG, Lamby EJ. Eutectic Salt Catalysts for Graphite and Coal Char Gasification. Fuel. 1985;64:805-9.

[26] Mckee DW. Rare-Earth-Oxides as Carbon Oxidation Catalysts. Carbon. 1985;23:707-13.

[27] Mckee DW, Chatterji D. Catalyzed Reaction of Graphite with Water-Vapor. Carbon. 1978;16:53-7.

[28] Mckee DW, Chatterji D. Catalytic Behavior of Alkali-Metal Carbonates and Oxides in Graphite Oxidation Reactions. Carbon. 1975;13:381-90.

[29] Mckee DW. Gasification of Graphite in Carbon-Dioxide and Water-Vapor - the Catalytic 
Effects of Alkali-Metal Salts. Carbon. 1982;20:59-66. 